\title{
A NECESSARY AND SUFFICIENT CONDITION FOR THE CONVEXITY OF THE GENERALIZED ELLIPTIC INTEGRAL OF THE FIRST KIND WITH RESPECT TO HÖLDER MEAN
}

\author{
HONG-Hu CHU AND WEI WANG
}

Abstract. In the article, we present the necessary and sufficient conditions such that the generalized elliptic integral and complete $p$-elliptic integral of the first kind are convex with respect to Hölder mean, which generalize and refine some previously known results.

Mathematics subject classification (2010): 33E05, 26A51, 26E60.

Keywords and phrases: Generalized elliptic integral, complete $p$-elliptic integral, Hölder mean, convexity.

\section{REFERENCES}

[1] I. Abbas Baloch And Y.-M. Chu, Petrović-type inequalities for harmonic h-convex Functions, J. Funct. Spaces, 2020 (2020), Article ID 3075390, 7 pages.

[2] M. Abramowitz AND I. A. STEgun, Handbook of Mathematical Functions with Formulas, Graphs, and Mathematical Tables, U. S. Government Printing Office, Washington, 1964.

[3] M. Adil Khan, M. Hanif, Z. A. H. Khan, K. Ahmad And Y.-M. ChU, Association of Jensen's inequality for s-convex function with Csiszár divergence, J. Inequal. Appl., 2019 (2019), Article 162, 14 pages.

[4] M. Adil Khan, A. Iqbal, M. Suleman and Y.-M. Chu, Hermite-Hadamard type inequalities for fractional integrals via Green's function, J. Inequal. Appl., 2018 (2018), Article 161, 15 pages.

[5] M. Adil Khan, Y. Khurshid, T.-S. Du And Y.-M. CHU, Generalization of Hermite-Hadamard type inequalities via conformable fractional integrals, J. Funct. Spaces, 2018 (2018), Article ID 5357463, 12 pages.

[6] M. Adil Khan, N. Mohammad, E. R. Nwaeze and Y.-M. Chu, Quantum Hermite-Hadamard inequality by means of a Green function, Adv. Difference Equ., 2020 (2020), Article 99, 20 pages.

[7] M. Adil Khan, S.-H. Wu, H. Ullah AND Y.-M. Chu, Discrete majorization type inequalities for convex functions on rectangles, J. Inequal. Appl., 2019 (2019), Article 16, 18 pages.

[8] M. Adil Khan, S. ZaheER Ullah And Y.-M. CHU, The concept of coordinate strongly convex functions and related inequalities, Rev. R. Acad. Cienc. Exactas Fís. Nat. Ser. A Mat. RACSAM, 113, 3 (2019), 2235-2251.

[9] H. AlZER AND S.-L. QIU, Monotonicity theorems and inequalities for the complete elliptic integrals, J. Comput. Appl. Math., 172, 2 (2004), 289-312.

[10] G. D. Anderson, S.-L. Qiu, M. K. Vamanamurthy and M. Vuorinen, Generalized elliptic integrals and modular equations, Pacific J. Math., 192, 1 (2000), 1-37.

[11] G. D. Anderson, M. K. Vamanamurthy and M. Vuorinen, Conformal Invariants, Inequalities, and Quasiconformal Maps, John Wiley \& Sons, New York, 1997.

[12] G. D. Anderson, M. K. Vamanamurthy and M. Vuorinen, Generalized convexity and inequalities, J. Math. Anal. Appl., 335, 2 (2007), 1294-1308.

[13] Á. BARICZ, Convexity of the zero-balanced Gaussian hypergeometric functions with respect to Hölder means, JIPAM. J. Inequal. Pure Appl. Math., 2007, 8, 2 (2007), Article 40, 9 pages.

[14] Á. BARICZ, B. A. BHAYO AND R. KLÉN, Convexity properties of generalized trigonometric and hyperbolic functions, Aequationes Math., 89, 3 (2015), 473-484.

[15] B. A. BhAYO AND M. VUORINEN, On generalized trigonometric functions with two parameters, J. Approx. Theory, 164, 10 (2012), 1415-1426. 
[16] J. M. Borwein AND P. B. Borwein, Pi and the AGM, John Wiley \& Songs, New York, 1987.

[17] Y.-M. ChU, M. Adil Khan, T. Ali AND S. S. Dragomir, Inequalities for $\alpha$-fractional differentiable functions, J. Inequal. Appl., 2017 (2017), Article 93, 12 pages.

[18] Y.-M. CHU AND B.-Y. LonG, Bounds of the Neuman-Sándor mean using power and identric means, Abstr. Appl. Anal., 2013 (2013), Article ID 832591, 6 pages.

[19] Y.-M. CHU, Y.-F. QIU AND M.-K. WANG, Hölder mean inequalities for the complete elliptic integrals, Integral Transforms Spec. Funct., 23, 7 (2012), 521-527.

[20] Y.-M. ChU AND M.-K. WANG, Optimal Lehmer mean bounds for the Toader mean, Results Math., 61, 3-4 (2012), 223-229.

[21] Y.-M. ChU, M.-K. WANG, Y.-P. JiAng AND S.-L. QIU, Concavity of the complete elliptic integrals of the second kind with respect to Hölder means, J. Math. Anal. Appl., 395, 2 (2012), 637-642.

[22] Y.-M. ChU, M.-K. WANG AND Y.-F. QIU, On Alzer and Qiu's conjecture for complete elliptic integral and inverse hyperbolic tangent function, Abstr. Appl. Anal., 2011 (2011), Article ID 697547, 7 pages.

[23] Y.-M. ChU, M.-K. WANG AND S.-L. QIU, Optimal combinations bounds of root-square and arithmetic means for Toader mean, Proc. Indian Acad. Sci. Math. Sci., 122, 1 (2012), 41-51.

[24] Y.-M. CHU, M.-K. WANG, S.-L. QIU AND Y.-P. JIANG, Bounds for complete elliptic integrals of the second kind with applications, Comput. Math. Appl., 63, 7 (2012), 1177-1184.

[25] Y.-M. ChU, S.-S. WANG AND C. ZoNG, Optimal lower power mean bound for the convex combination of harmonic and logarithmic means, Abstr. Appl. Anal., 2011 (2011), Article ID 520648, 9 pages.

[26] Y.-M. ChU, Z.-H. YAng AND L.-M. WU, Sharp power mean bounds for Sándor mean, Abstr. Appl. Anal., 2015 (2015), Article ID 172867, 5 pages.

[27] Y.-M. ChU AND T.-H. ZhaO, Concavity of the error function with respect to Hölder means, Math. Inequal. Appl., 19, 2 (2016), 589-595.

[28] X.-H. He, W.-M. Qian, H.-Z. XU And Y.-M. ChU, Sharp power mean bounds for two SándorYang means, Rev. R. Acad. Cienc. Exactas Fís. Nat. Ser. A Mat. RACSAM 113, 3 (2019), 2627-2638.

[29] X.-M. HU, J.-F. Tian, Y.-M. ChU AND Y.-X. LU, On Cauchy-Schwarz inequality for N-tuple diamond-alpha integral, J. Inequal. Appl., 2020 (2020), Article 8, 15 pages.

[30] C.-X. Huang, S. GuO And L.-Z. Liu, Boundedness on Morrey space for Toeplitz type operator associated to singular integral operator with variable Calderón-Zygmund kernel, J. Math. Inequal., 8 , 3 (2014), 453-464.

[31] T.-R. HuAnG, B.-W. Han, X.-Y. MA AND Y.-M. ChU, Optimal bounds for the generalized EulerMascheroni constant, J. Inequal. Appl., 2018 (2018), Article 118, 9 pages.

[32] C.-X. HUANG AND L.-Z. LiU, Sharp function inequalities and boundness for Toeplitz type operator related to general fractional singular integral operator, Publ. Inst. Math., 92, 106 (2012), 165-176.

[33] C.-X. HUANG AND L.-Z. LiU, Boundedness of multilinear singular integral operator with a nonsmooth kernel and mean oscillation, Quaest. Math., 40, 3 (2017), 295-312.

[34] T.-R. HuAnG, S.-Y. TAN, X.-Y. MA AND Y.-M. CHU, Monotonicity properties and bounds for the complete p-elliptic integrals, J. Inequal. Appl., 2018, (2018), Article 239, 11 pages.

[35] C.-X. HuAng, Z.-C. YAnG, T.-S. YI AND X.-F. Zou, On the basins of attraction for a class of delay differential equations with non-monotone bistable nonlinearities, J. Differential Equations, 256, 7 (2014), 2101-2114.

[36] C.-X. Huang, H. Zhang, J.-D. CaO And H.-J. Hu, Stability and Hopf bifurcation of a delayed prey-predator model with disease in the predator, Commun. Internat. J. Bifur. Chaos Appl. Sci. Engrg., 29, 7 (2019), Article ID 1950091, 23 pages.

[37] C.-X. HUANG, H. ZhANG AND L.-H. HUANG, Almost periodicity analysis for a delayed Nicholson's blowflies model with nonlinear density-dependent mortality term, Commun. Pure Appl. Anal., 18, 6 (2019), 3337-3349.

[38] D. B. KARP AND E. G. PRILEPKINA, Parameter convexity and concavity of generalized trigonometric functions, J. Math. Anal. Appl., 421, 1 (2015), 370-382.

[39] S. Khan, M. Adil Khan And Y.-M. Chu, Converses of the Jensen inequality derived from the Green functions with applications in information theory, Math. Methods Appl. Sci., 43, 5 (2020), 2577-2687.

[40] M. A. LATif, S. Rashid, S. S. Dragomir And Y.-M. ChU, Hermite-Hadamard type inequalities for co-ordinated convex and qausi-convex functions and their applications, J. Inequal. Appl., 2019 (2019), Article 317, 33 pages.

[41] Y.-M. LI, B.-Y. LONG AND Y.-M. CHU, Sharp bounds by the power mean for the generalized Heronian mean, J. Inequal. Appl., 2012 (2012), Article 129, 9 pages. 
[42] F.-W. LiU, L.-B. FENG, V. ANH AND J. Li, Unstructured-mesh Galerkin finite element method for the two-dimensional multi-term time-space fractional Bloch-Torrey equations on irregular convex domains, Comput. Math. Appl., 78, 5 (2019), 1637-1650.

[43] F. W. J. Olver, D. W. Lozier, R. F. Boisvert And C. W. Clark, NIST Handbook of Mathematical Functions, Cambridge University Press, Cambridge, 2010.

[44] W.-M. QIAN, Z.-Y. HE AND Y.-M. CHU, Approximation for the complete elliptic integral of the first kind, Rev. R. Acad. Cienc. Exactas Fís. Nat. Ser. A Mat. RACSAM 14, 2 (2020), Article 57, DOI: 10.1007/s13398-020-00784-9.

[45] W.-M. QIAN, Z.-Y. HE, H.-W. ZHANG AND Y.-M. CHU, Sharp bounds for Neuman means in terms of two-parameter contraharmonic and arithmetic mean, J. Inequal. Appl., 2019 (2019), Article 168, 13 pages.

[46] W.-M. QiAn, Y.-Y. YANG, H.-W. Zhang AND Y.-M. CHU, Optimal two-parameter geometric and arithmetic mean bounds for the Sándor-Yang mean, J. Inequal. Appl., 2019 (2019), Article 287, 12 pages.

[47] W.-M. QIAN, W. ZHANG AND Y.-M. CHU, Bounding the convex combination of arithmetic and integral means in terms of one-parameter harmonic and geometric means, Miskolc Math. Notes, 20, 2 (2019), 1157-1166.

[48] S.-L. QIU, X.-Y. MA AND Y.-M. CHU, Sharp Landen transformation inequalities for hypergeometric functions, with applications, J. Math. Anal. Appl., 474, 2 (2019), 1306-1337.

[49] S.-L. QIU, Y.-F. QIU, M.-K. WANG AND Y.-M. CHU, Hölder mean inequalities for the generalized Grötzsch ring and Hersch-Pfluger distortion functions, Math. Inequal. Appl., 15, 1 (2012), 237-245.

[50] S. Rafeeq, H. Kalsoom, S. Huss ain, S. Rashid And Y.-M. CHu, Delay dynamic double integral inequalities on time scales with applications, Adv. Difference Equ., 2020 (2020), Article 40, 32 pages.

[51] Y.-Q. Song, M. Adil Khan, S. Zaheer Ullah and Y.-M. Chu, Integral inequalities involving strongly convex functions, J. Funct. Spaces, 2018 (2018), Article ID 6595921, 8 pages.

[52] S. TAKEUCHI, A new form of the generalized complete elliptic integrals, Kodai Math. J., 39, 1 (2016), 202-226.

[53] S. TAKEUCHI, Multiple-angle formulas of generalized trigonometric functions with two parameters, J. Math. Anal. Appl., 444, 2 (2016), 1000-1014.

[54] S. TAKEUCHI, Legendre-type relations for generalized complete elliptic integrals, J. Class. Anal., 9, 1 (2016), 35-42.

[55] S. TAKEUCHI, Complete $p$-elliptic integrals and a computation formula of $\pi_{p}$ for $p=4$, Ramanujan J., 46, 2 (2018), 309-321.

[56] J.-F. WANG, X.-Y. ChEN AND L.-H. HuAng, The number and stability of limit cycles for planar piecewise linear systems of node-saddle type, J. Math. Anal. Appl., 469, 1 (2019), 405-427.

[57] M.-K. WANG AND Y.-M. CHU, Asymptotical bounds for complete elliptic integrals of the second kind, J. Math. Anal. Appl., 402, 1 (2013), 119-126.

[58] M.-K. WANG AND Y.-M. CHU, Refinements of transformation inequalities for zero-balanced hypergeometric functions, Acta Math. Sci., 37B, 3 (2017), 607-622.

[59] M.-K. WANG AND Y.-M. CHU, Landen inequalities for a class of hypergeometric functions with applications, Math. Inequal. Appl., 21, 2 (2018), 521-537.

[60] M.-K. WAng, H.-H. CHU AND Y.-M. CHU, Precise bounds for the weighted Hölder mean of the complete p-elliptic integrals, J. Math. Anal. Appl., 480, 2 (2019), Article ID 123388, 9 pages, DOI: 10.1016/j.jmaa.2019.123388.

[61] M.-K. WANG, Y.-M. CHU AND Y.-P. JiAng, Ramanujan's cubic transformation inequalities for zero-balanced hypergeometric functions, Rocky Mountain J. Math., 46, 2 (2016), 679-691.

[62] M.-K. WANG, Y.-M. CHU, S.-L. QIU AND Y.-P. JiAnG, Convexity of the complete elliptic integrals of the first kind with respect to Hölder means, J. Math. Anal. Appl., 2012, 388, 2 (2012), 1141-1146.

[63] M.-K. WAng, Y.-M. ChU, Y.-F. QIU AND S.-L. QIU, An optimal power mean inequality for the complete elliptic integrals, Appl. Math. Lett., 24, 6 (2011), 887-890.

[64] M.-K. WAng, Y.-M. CHU AND Y.-Q. Song, Asymptotical formulas for Gaussian and generalized hypergeometric functions, Appl. Math. Comput., 276 (2016), 44-60.

[65] M.-K. WANG, Y.-M. ChU AND W. Zhang, Monotonicity and inequalities involving zero-balanced hypergeometric function, Math. Inequal. Appl., 22, 2 (2019), 601-617.

[66] M.-K. WAng, Y.-M. Chu And W. Zhang, Precise estimates for the solution of Ramanujan's generalized modular equation, Ramanujan J., 49, 3 (2019), 653-668.

[67] M.-K. WANG, Z.-Y. HE AND Y.-M. CHU, Sharp power mean inequalities for the generalized elliptic integral of the first kind, Comput. Methods Funct. Theory, 20, 1 (2020), 111-124. 
[68] M.-K. WANG, M.-Y. Hong, Y.-F. Xu, Z.-H. ShEN AND Y.-M. CHU, Inequalities for generalized trigonometric and hyperbolic functions with one parameter, J. Math. Inequal., 14, 1 (2020), 1-21.

[69] J.-F. WAng, C.-X. Huang AND L.-H. Huang, Discontinuity-induced limit cycles in a general planar piecewise linear system of saddle-focus type, Nonlinear Anal. Hybrid Syst., 33 (2019), 162 178.

[70] M.-K. WANG, Y.-M. LI AND Y.-M. CHU, Inequalities and infinite product formula for Ramanujan generalized modular equation function, Ramanujan J., 46, 1 (2018), 189-200.

[71] B. WANG, C.-L. LuO, S.-H. Li AND Y.-M. CHU, Sharp one-parameter geometric and quadratic means bounds for the Sándor-Yang means, Rev. R. Acad. Cienc. Exactas Fís. Nat. Ser. A Mat. RACSAM, 114, 1 (2020), Article 7, DOI: 10.1007/s13398-019-00734-0.

[72] H. WANG, W.-M. QIAN AND Y.-M. CHU, Optimal bounds for Gaussian arithmetic-geometric mean with applications to complete elliptic integral, J. Funct. Spaces, 2016 (2016), Article ID 3698463, 6 pages.

[73] J.-L. WANG, W.-M. QIAN, Z.-Y. HE AND Y.-M. ChU, On approximating the Toader mean by other bivariate means, J. Funct. Spaces, 2019 (2019), Article ID 6082413, 7 pages.

[74] M.-K. WANG, S.-L. QIU, Y.-M. ChU AND Y.-P. JiAnG, Generalized Hersch-Pfluger distortion function and complete elliptic integrals, J. Math. Anal. Appl., 385, 1 (2012), 221-229.

[75] G.-D. WANG, X.-H. ZHANG AND Y.-M. CHU, A power mean inequality for the Grötzsch ring function, Math. Inequal. Appl., 14, 4 (2011), 833-837.

[76] G.-D. WANG, X.-H. Zhang AND Y.-M. ChU, A power mean inequality involving the complete elliptic integrals, Rocky Mountain J. Math., 44, 5 (2014), 1661-1667.

[77] M.-K. WANG, W. Zhang AND Y.-M. ChU, Monotonicity, convexity and inequalities involving the generalized elliptic integrals, Acta Math. Sci., 39B, 5 (2019), 1440-1450.

[78] S.-H. WU AND Y.-M. ChU, Schur m-power convexity of generalized geometric Bonferroni mean involving three parameters, J. Inequal. Appl., 2019 (2019), Article 57, 11 pages.

[79] W.-F. XIA, W. JANOUS AND Y.-M. CHU, The optimal convex combination bounds of arithmetic and harmonic means in terms of power mean, J. Math. Inequal., 6, 2 (2012), 241-248.

[80] Z.-H. YANG AND Y.-M. CHU, A monotonicity property involving the generalized elliptic integral of the first kind, Math. Inequal. Appl., 20, 3 (2017), 729-735.

[81] Z.-H. YANG, Y.-M. CHU AND W. ZHANG, High accuracy asymptotic bounds for the complete elliptic integral of the second kind, Appl. Math. Comput., 348 (2019), 552-564.

[82] Z.-H. YANG, W.-M. QIAN AND Y.-M. CHU, Monotonicity properties and bounds involving the complete elliptic integrals of the first kind, Math. Inequal. Appl., 21, 4 (2018), 1185-1199.

[83] Z.-H. YANG, W.-M. QIAN, Y.-M. ChU AND W. ZHANG, On rational bounds for the gamma function, J. Inequal. Appl., 2017 (2017), Article 210, 17 pages.

[84] Z.-H. YANG, W.-M. QIAN, Y.-M. ChU AND W. Zhang, On approximating the arithmeticgeometric mean and complete elliptic integral of the first kind, J. Math. Anal. Appl., 462, 2 (2018), $1714-1726$.

[85] Z.-H. YANG, W.-M. QIAN, W. ZhANG AND Y.-M. ChU, Notes on the complete elliptic integral of the first kind, Math. Inequal. Appl., 23, 1 (2020), 77-93.

[86] S. Zaheer Ullah, M. Adil Khan and Y.-M. ChU, Majorization theorems for strongly convex functions, J. Inequal. Appl., 2019 (2019), Article 58, 13 pages.

[87] S. Zaheer Ullah, M. Adil Khan and Y.-M. ChU, A note on generalized convex functions, J. Inequal. Appl., 2019 (2019), Article 291, 10 pages.

[88] S. Zaheer Ullah, M. Adil Khan, Z. A. Khan and Y.-M. Chu, Integral majorization type inequalities for the functions in the sense of strong convexity, J. Funct. Spaces, 2019 (2019), Article ID 9487823, 11 pages.

[89] X.-H.ZHANG, Monotonicity and functional inequalities for the complete p-elliptic integrals, J. Math. Anal. Appl., 453, 2 (2017), 942-953.

[90] X.-H. Zhang, G.-D. WANG AND Y.-M. ChU, Convexity with respect to Hölder mean involving zero-balanced hypergeometric functions, J. Math. Anal. Appl., 353, 1 (2009), 256-259.

[91] T.-H. ZHAO, Y.-M. CHU AND H. WANG, Logarithmically complete monotonicity properties relating to the gamma function, Abstr. Appl. Anal., 2011 (2011), Article ID 896483, 13 pages.

[92] T.-H.ZHAO, L. SHI AND Y.-M. ChU, Convexity and concavity of the modified Bessel functions of the first kind with respect to Hölder means, Rev. R. Acad. Cienc. Exactas Fís. Nat. Ser. A Mat. RACSAM, 114, 2 (2020), Article 96, DOI: 10.1007/s13398-020-00825-3.

[93] T.-H. ZhaO, M.-K. WANG, W. Zhang AND Y.-M. ChU, Quadratic transformation inequalities for Gaussian hypergeometric function, J. Inequal. Appl., 2018 (2018), Article 251, 15 pages.

[94] W.-J. ZHOU AND X.-L. CHEN, On the convergence of a modified regularized Newton method for 
convex optimization with singular solutions, J. Comput. Appl. Math., 239 (2013), 179-188.

[95] L.-M.ZHOU, S.-L. QIU AND F. WANG, Inequalities for the generalized elliptic integrals with respect to Hölder means, J. Math. Anal. Appl., 386, 2 (2012), 641-646. 